\title{
DEMENTIA PUGILISTICA WITH CLINICAL FEATURES OF ALZHEIMER'S DISEASE
}

\author{
Renata Areza-Fegyveres', Sergio Rosemberg ${ }^{2}$, Rosa Maria R.P.S. Castro ${ }^{3}$, \\ Claudia Sellitto Porto ${ }^{1}$, Valéria Santoro Bahia ${ }^{1}$, Paulo Caramelli ${ }^{1}$, Ricardo Nitrini ${ }^{1}$
}

\begin{abstract}
A 61-year-old ex-boxer presented with a three-year history of progressive memory decline. During a seven-year follow-up period, there was a continuous cognitive decline, very similar to that usually observed in Alzheimer's disease. Parkinsonian, pyramidal or cerebellar signs were conspicuously absent. Neuropathological examination revealed the typical features of dementia pugilistica: cavum septi pellucidi with multiple fenestrations, numerous neurofibrillary tangles in the cerebral isocortex and hippocampus (and rare senile plaques). Immunohistochemistry disclosed a high number of tau protein deposits and scarce beta-amyloid staining. This case shows that dementia pugilistica may present with clinical features practically undistinguishable from Alzheimer's disease.
\end{abstract}

KEY WORDS: dementia, dementia pugilistica, punch drunk, Alzheimer's disease, chronic traumatic encephalopathy, parkinsonian/motor signs, neuropathology.

\begin{abstract}
Dementia pugilistica com características clínicas de doença de Alzheimer
RESUMO - Um ex-boxeador de 61 anos apresentou-se com história de três anos de perda progressiva de memória e evoluiu com declínio cognitivo lentamente progressivo, sugestivo de doença de Alzheimer, durante seguimento de sete anos. Sinais parkinsonianos, piramidais ou cerebelares estiveram ausentes durante toda a evolução. Exame neuropatológico evidenciou características típicas de dementia pugilistica: cavum do septo pelúcido com múltiplas fenestrações, numerosos emaranhados neurofibrilares no isocórtex cerebral e hipocampo (e raras placas senis). Imuno-histoquímica confirmou número elevado de depósitos de proteína tau e raros de beta-amilóide. Este caso demonstra que dementia pugilistica pode apresentar quadro clínico indistinguível daquele da doença de Alzheimer.
\end{abstract}

PALAVRAS-CHAVE: demência, dementia pugilistica, síndrome punch-drunk, doença de Alzheimer, encefalopatia traumática crônica, sinais motores/parkinsonianos, neuropatologia.

Martland, in 1928 ${ }^{1}$, first brought the expression "punch drunk syndrome" to medical literature, hitherto used by the lay public and boxing fans to name the condition that some boxers develop during or after their fighting career. The syndrome consisted of extrapyramidal and cerebellar signs and symptoms, associated or not, with cognitive and behavioral abnormalities. In 1937, the designation "dementia pugilistica" was proposed². Critchley, in $1957^{3}$, named it "chronic progressive encephalopathy of the boxer", being more descriptive in that it represents the long term cumulative effect of repetitive head trau$m a^{1,3-5}$. However, the label dementia pugilistica has been more frequently used.

We report the clinical and neuropathological findings of a case of dementia pugilistica presenting a cognitive profile similar to Alzheimer's disease (AD). Informed consent to publish these data was given by the patient's wife and son.

\section{CASE}

The patient was a 61 year-old former boxer with six years of education, who presented with a three-year history of memory decline in which he kept forgetting recent events, names of known relatives and where he had left objects. The memory disturbance was followed by spatial disorientation in surroundings. He began amateur boxing at the age of 16 and had fought for 14 years as an amateur, and three years as a professional boxer in the "fly-weight" category. He fought more than 60 bouts, including SouthAmerican and international competitions and won the majority of his contests. He lost 4 fights on points, but had never been knocked-out. He was a heavy smoker, and had undergone gastric surgery forty years earlier. Also, he had

\footnotetext{
${ }^{1}$ Behavioral and Cognitive Neurology Unit, Department of Neurology, University of São Paulo School of Medicine, São Paulo SP, Brazil; '2Department of Pathology, University of São Paulo School of Medicine, São Paulo SP, Brazil; ${ }^{3}$ Ludwig Institute for Cancer Research, Sao Paulo Branch, Sao Paulo SP, Brazil.
}

Received 18 January 2007, received in final form 8 May 2007. Accepted 15 June 2007. 
no history of psychiatric disturbances, alcoholism or drug abuse and no family history of dementia. General physical examination revealed no abnormalities. On neurological examination, he scored 24 points in the Mini-Mental State Examination ${ }^{6}$. Muscle power, sensory system, cranial nerves, equilibrium, kinesis, muscle tonus, coordination, deep tendon and superficial reflexes were all normal.

Neuropsychological evaluation showed predominant memory impairment. The total score on the Mattis Dementia Rating Scale (Mattis DRS) ${ }^{7}$ was 104 points out of 144, with greater impairment in the memory subscale.

A thorough laboratory investigation including cerebrospinal fluid analysis was unremarkable. Apolipoprotein $\varepsilon$ allele polymorphism detected the $\varepsilon 3 / \varepsilon 3$ genotype. Computed tomography (CT) scans revealed enlargement of the $3^{\text {rd }}$ and lateral ventricles, cortico-subcortical atrophy and presence of cavum septi pellucidi. Magnetic resonance imaging studies confirmed the CT findings. Single photon emission computed tomography showed mild hypoperfusion of the frontal lobes bilaterally.

This patient was followed with at least two medical evaluations a year for seven years. No cerebellar, pyramidal or extrapyramidal signs were seen during the follow-up period. His cognitive impairment steadily worsened. During the follow-up, the Mattis DRS total score decreased to 101 after six months, falling to 86 points after four years. With progression of the disease, predominant impairment in memory, attention and executive functions were confirmed by poor performance in memory subtests from the Wechsler Memory Scale ${ }^{8}$, the Visual Retention Test: Multiple Choice9, the Block Design (Wechsler Adult Intelligence Scale - WAIS $)^{10}$, the Hooper visual Organization Test ${ }^{11}$, the Trail Making Test ${ }^{12}$, the Maze Test ${ }^{13}$ and the category fluency test (animals per minute).

Rivastigmine was prescribed for approximately one year and gradually titrated to $6 \mathrm{mg}$ BID with dubious results.
Death occurred seven years after the first consultation and was caused by gastric adenocarcinoma.

Macroscopic examination of the brain at autopsy showed moderate and symmetric atrophy, particularly of the frontal and temporal lobes, along with moderate enlargement of the lateral ventricles, especially at the level of the inferior horns. Presence of total cavum septi pellucidi, and a very thin septum with multiple fenestrations across almost its full extension was evident (Fig 1).

Slices were taken from the cingulate gyrus, frontal, parietal, temporal, and occipital cortices, hippocampus, lenticular nucleus, thalamus, amygdala, midbrain, pons, medulla, cerebellar cortex, and dentate nucleus. All fragments were stained with H\&E, Bielschowsky and Nissl stains, and Weil method for myelin. Immunohistochemistry was performed with the GFAP antibodies (Dako A/S, Denmark, M0761, clone 6F2, monoclonal mouse anti human glial fibrillary acidic protein); ubiquitin (Dako A/S, Denmark, Z0458, polyclonal Ab-rabbit anti-human ubiquitin); beta-amiloid (Dako A/S, Denmark, M0872, clone 6F/3D, monoclonal mouse Ab- residue 8-17); tau protein (Dako A/S, Denmark, A0024, polyclonal Tau-P); GSK3 beta (Chemicon International Inc., USA, AB8687, polyclonal rabbit anti glycogen synthase kinase 3 beta); and alpha-synuclein (Chemicon International Inc., USA, AB5038, polyclonal rabbit anti synuclein alpha); using hydrolytic microwave antigenic retrieval and detection with peroxidase Ab-Dako EnVision Labelled Polymer (Dako Corporation, USA).

Microscopic examination on H\&E stain showed mild to moderate neuronal loss and reactive gliosis in all isocortical structures, predominantly at the frontal and temporal lobes. Intense neuronal loss with reactive gliosis at the CA1 sector was evident, along with less intense loss in the CA4 sector of the hippocampus. Basal ganglia, thalami, brain stem and cerebellum were unremarkable, except for the presence of neurofibrillary degeneration of some neu-

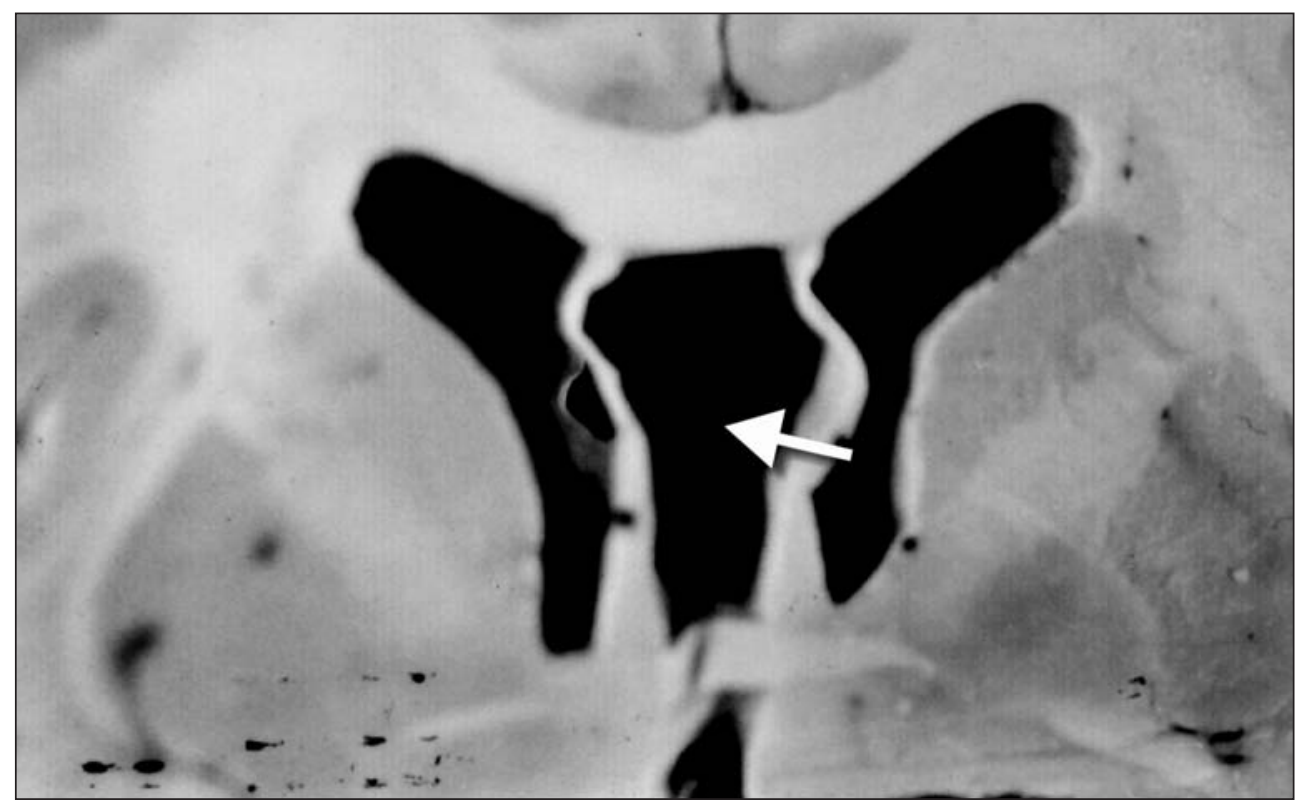

Fig 1. Macroscopic analysis: coronal slice showing the cavum of septi pellucidi. 


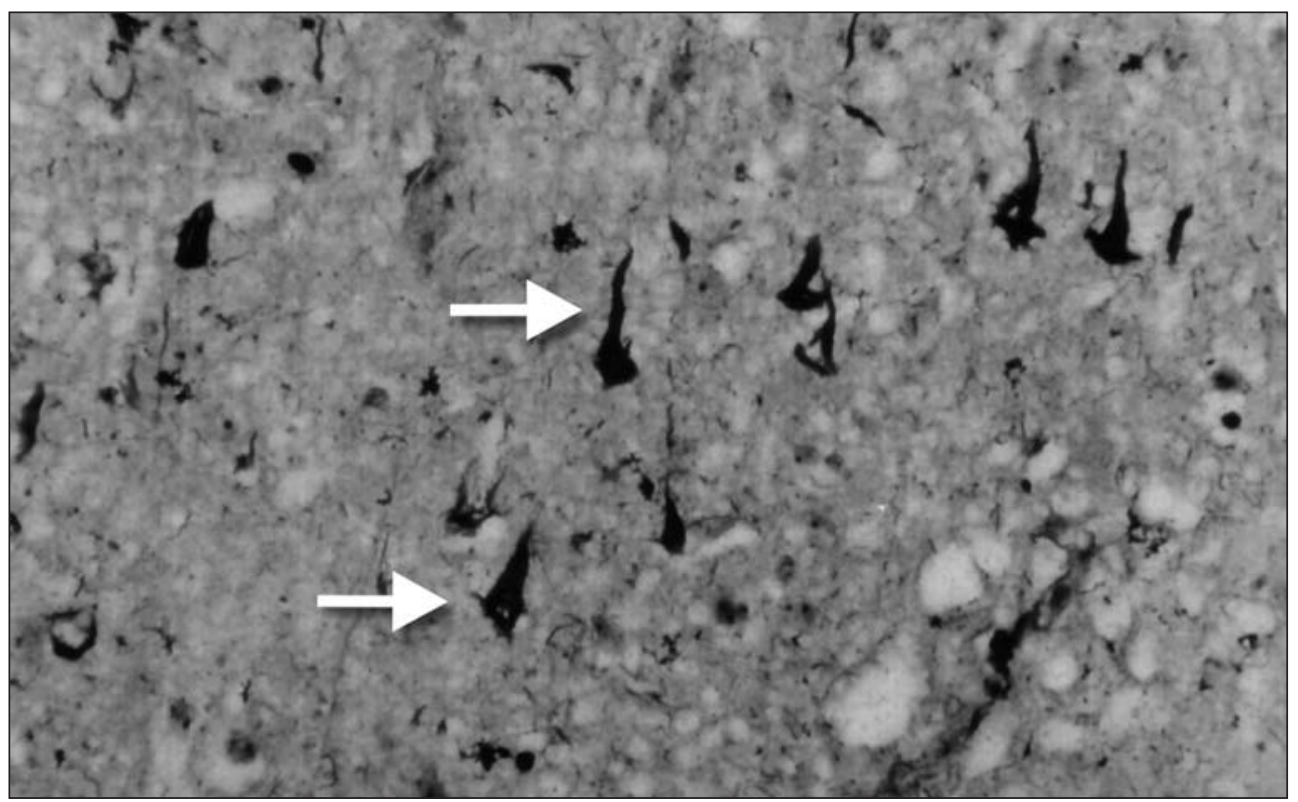

Fig 2. Imunohistochemistry of frontal cortex: neurofibrillary tangles. Bielschowsky method X 400 .

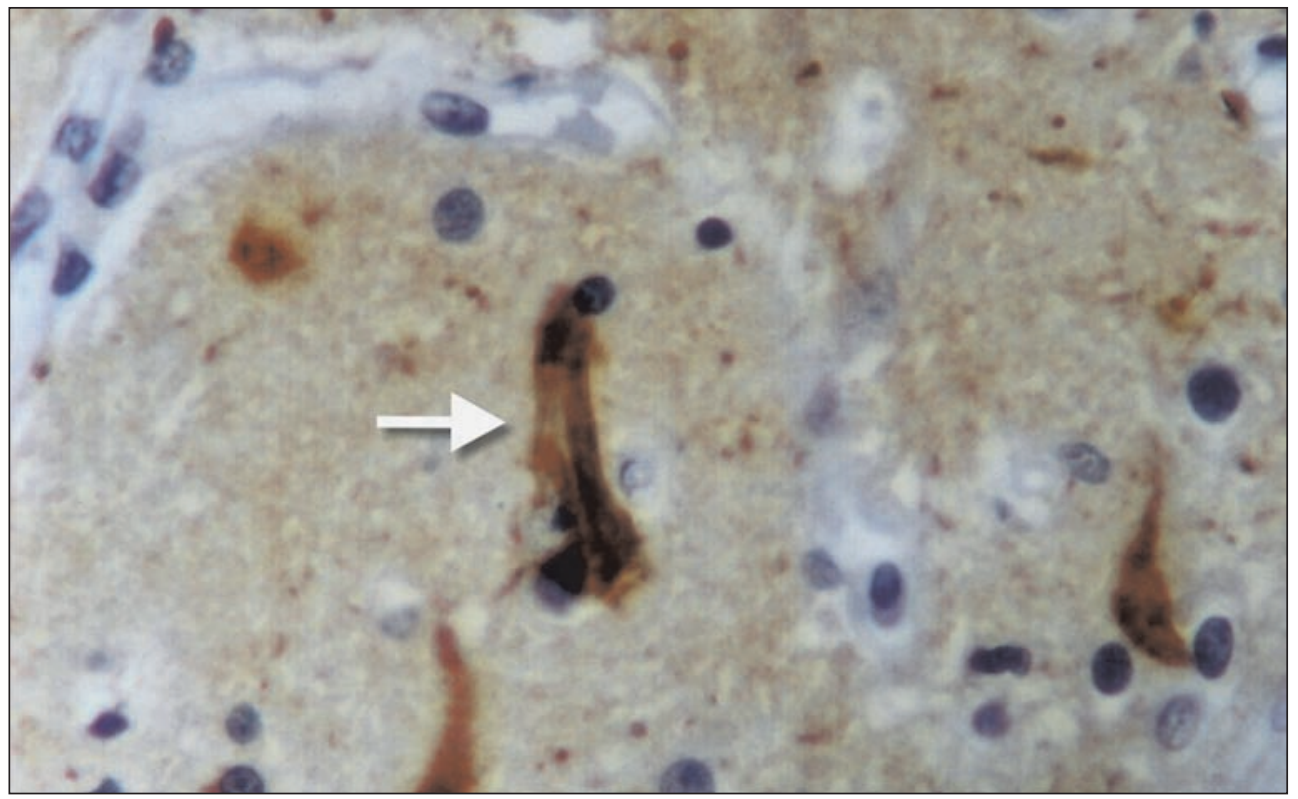

Fig 3. Imunohistochemistry of frontal cortex: tau protein deposits: polyclonal antibody $X 400$.

rons of the substantia nigra and locus coeruleus. However, moderate reactive gliosis was detected at the putamen and thalamus on GFAP stain. Status spongiosus was absent. Neurofibrillary tangles detected through Bielschowsky (Fig 2) and tau protein stains (Fig 3) were present in large amounts ( 5 to 6 per high power field-HPF) at the CA4, CA1 sectors of the hippocampus, at the pre-subicullum, subicullum and entorhinal cortex. They were present in moderate amounts ( 1 to 3 per HPF) at the frontal, cingulate, temporal and parietal cortices, and absent at the occipital cortex. Rare beta-amyloid senile plaques were found only at the subicullum and entorhinal cortex. Thread-like deposits were absent in all structures. Granulo-vacuolar degen- eration was not detected. GSK3 beta and alpha synuclein stains gave negative results.

\section{DISCUSSION}

The exclusively cognitive impairment with predominant memory decline we are reporting in this case differs from the typical case of dementia pugilistica described in the literature. Furthermore, the pattern of cognitive decline was also different from the usual cases. In a broad review of this topic, Mende $z^{5}$ analyzed studies including 274 professional boxers, 
which revealed difficulties in sequencing abilities, complex attention tasks, frontal-executive functions, memory, information processing speed and fingertapping speed. These cognitive abnormalities are indicative of frontal-subcortical dysfunction. In the case we are now describing, the cognitive decline was more suggestive of $A D$, with memory impairment followed by topographical disorientation.

A few cases of DP without motor signs have already been described, but in these reports either neuropsychological evaluations were absent and/ or pathological study was not performed ${ }^{1-3,14,15}$. Rochon ${ }^{14}$ reported a case of an ex-boxer, who presented memory impairment and aggressive behavior, with no motor signs. The neuropsychological evaluation showed mild anomia, disinhibition, difficulty in maintaining an effective action strategy, slower speed in the left hand, mental inflexibility and mild perseveration, which are suggestive of frontal-subcortical dysfunction. Naccache et al. ${ }^{15}$ also reported a case of an ex-boxer with memory impairment and highlighted the absence of motor signs. The subject's neuropsychological evaluation showed severe memory impairment and executive dysfunction. In Brazil, Cordeiro-Junior and Oliveira reported a case of a 67-year-old ex-boxer that developed neuropsychiatric manifestations (psychotic syndrome and memory and spatial orientation deficits) after the end of his sportive career possibly due to successive brain injuries related to boxing ${ }^{16}$. However, in the above described cases, neuropathological examinations were not performed.

The neuropathological findings of our case are those usually described in dementia pugilistica, which consist of septum pellucidum alterations (cavum and fenestrations), cerebellar atrophy with Purkinje neuronal loss; degeneration and loss of substantia nigra pigmented cells, presence of neurofibrillary tangles (NFT) throughout the cortex and the brain stem, especially in the uncus, cortico-medial section of amygdaloid nucleus, fusiform and para-hippocampal gyri, lateral temporal, insular and frontal cortices; paucity or absence of senile plaques (SP) ${ }^{17}$.

Dementia pugilistica has been included among the acquired tauopathies, and its pathophysiology is still poorly understood ${ }^{18}$. Geddes et al. ${ }^{19}$ examined the brains of four young men, and a frontal lobectomy specimen from a fifth individual, who all had a history of traumatic brain injury in common, only for different reasons (including 2 boxers). They concluded that repetitive head injury in young adults is initially associated with neocortical NFT formation in the absence of $A \beta$ deposition and that the distribution of tau pathology around the vessels in two of the five brains examined suggested that the pathogenesis of cytoskeletal abnormalities may involve damage to blood vessels or perivascular elements.

In the case we are now reporting, the differential diagnosis from $A D$ proved very difficult when based solely on clinical grounds, in spite of systematic neurological and neuropsychological evaluations. However, the neuropathological findings were typical of dementia pugilistica.

\section{REFERENCES}

1. Martland HS. Punch drunk. J Am Med Assoc 1928;91:1103-1107.

2. Millspaugh JA. Dementia pugilistica. United States Naval Medicine Bulletin 1937;35:297-303.

3. Critchley M. Medical aspects of boxing: particularly from a neurological standpoint. Br Med J 1957;1:357-362.

4. Roberts AH. Brain damage in boxers: a study of the prevalence of traumatic encephalopathy among ex-professional boxers. London: Pitman Medical and Scientific Publishing Company, Ltd., 1969.

5. Mendez MF. The neuropsychiatric aspects of boxing. Int J Psychiatry Med 1995;25:249-262.

6. Folstein MF, Folstein SE, McHugh PR. "Mini-mental state: a practical method for grading the cognitive state of patients for the clinician. J Psychiatr Res 1975;12:189-198.

7. Mattis S. Dementia rating scale: professional manual. Florida: Psychological Assessment Resources, Inc, 1988.

8. Wechsler D. Wechsler Memory Scale - Revised. New York: The Psychological Corporation, 1987.

9. Benton AL, Hamsher KS, Stone FB. Visual Retention Test: multiple choice I. Iowa: Division of Behavioral Neurology, Department of Neurology, University of Iowa Hospitals, 1977.

10. Wechsler D. Wechsler Adult Intelligence Scale. New York: Grune and Stratton, 1976.

11. Hooper HE. Hooper Visual Organization Test (HVOT): manual. Los Angeles: Western Psychological Services, 1983.

12. Spreen O, Strauss E. A compendium of neuropsychological tests: administration, norms and commentary, 2.Ed. New York: Oxford University Press, 1998.

13. Lezak, MD. Neuropsychological assessment. 3.Ed. New York: Oxford University Press, 1995.

14. Rochon M. Présentation d'un cas: l'encephalopathie des boxeurs. Can J Psychiatry 1994;39:211-214.

15. Naccache L, Slachevsky A, Deweer B, Habert MO, Dubois B. “Démence pugilistique" sans signes moteurs. Press Med 1999;28:1352-1354.

16. Cordeiro-Junior Q, Oliveira AM. Parkinsonian, cerebellar, psychotic and demential symptoms in ex-boxer: case report. Arq Neuropsiquiatr 2001; 59:283-285.

17. Corsellis JAN, Bruton CJ, Freeman-Browne D. The aftermath of boxing. Psychol Med 1973;270-303.

18. Lace GL, Wharton SB, Ince PG. A brief history of tau: the evolving view of the microtubule-associated protein tau in neurodegenerative diseases. Clin Neuropathol 2007;26:43-58.

19. Geddes JF, Vowels GH, Nicoll JAR, Révèsz T. Neuronal citoskeletal changes are an early consequence of repetitive head injury. Acta Neurpathol 1999;98:171-178. 